\title{
A new species of Petrolisthes (Crustacea, Anomura, Porcellanidae) inhabiting vermetid formations (Mollusca, Gastropoda, Vermetidae) in the southern Caribbean Sea
}

\author{
Alexandra Hiller', Bernd Werding ${ }^{2}$ \\ I Smithsonian Tropical Research Institute, Apartado 0843-03092, Panamá, República de Panamá 2 Institut für \\ Tierökologie und Spezielle Zoologie der Justus-Liebig-Universität Giessen, Heinrich-Buff-Ring 29 (Tierhaus), \\ D-35392 Giessen, Germany
}

Corresponding author: Alexandra Hiller (hillera@si.edu)

Academic editor: I. Wehrtmann | Received 13 June 2019 | Accepted 18 August 2019 | Published 25 September 2019

http://zoobank.org/E1FA254C-40CC-42D8-AC6A-FBF9855B80E5

Citation: Hiller A, Werding B (2019) A new species of Petrolisthes (Crustacea, Anomura, Porcellanidae) inhabiting vermetid formations (Mollusca, Gastropoda, Vermetidae) in the southern Caribbean Sea. ZooKeys 876: 143-151. https://doi.org/10.3897/zookeys.876.37244

\begin{abstract}
Petrolisthes virgilius sp. nov. from the Caribbean Sea of Colombia is described. The new species resembles P. tonsorius morphologically but differs from it principally by its color and habitat. Petrolisthes tonsorius is brown or blueish brown and occurs under intertidal boulders strongly exposed to water movement. Petrolisthes virgilius sp. nov. is pale brown to beige and lives exclusively in intertidal areas dominated by vermetid snails, exposed to heavy wave action. The entangled tubular shells of vermetids are cemented to each other and to a hard substrate like beach rock, forming a microhabitat for the new crab species and other porcellanids of the genera Neopisosoma and Clastotoechus. Large genetic distances between DNA sequences of the mitochondrial 16S rDNA gene from P. virgilius sp. nov. and P. tonsorius confirmed that they comprise different species. Petrolisthes virgilius sp. nov. is the $53^{\text {rd }}$ member of the West Atlantic porcellanid fauna.
\end{abstract}

\section{Keywords}

West Atlantic, Petrolisthes virgilius sp. nov., Petrolisthes tonsorius, ecological differences, color morphs, vermetid formations, mitochondrial marker 


\section{Introduction}

The porcellanid fauna of the western Atlantic has been studied intensively in the last 60 years. With the last additions by Ferreira and Tavares $(2017,2019)$ and Werding and Hiller (2017), consisting of three new species of Pachycheles Stimpson, the number of western Atlantic species rose to 52. Werding (1978) found individuals of Petrolisthes inhabiting vermetid formations in the Colombian Gulf of Urabá, and assigned them to P. tonsorius Haig, 1960, but warned that coloration and habitat of the crab specimens were atypical. Petrolisthes tonsorius inhabits the rocky intertidal of both the Caribbean and the tropical East Pacific and exhibits a brown to dark-brown color (Fig. 1a), sometimes blueish (Fig. 1b). The individuals found inhabiting vermetid formations were pale brown to beige (Fig. 2). Morphological re-examination of this color morph, and genetic distances estimated between DNA sequences of the 16S rDNA gene from this new form and $P$. tonsorius confirmed that they comprise different species. Here we describe the new form as Petrolisthes virgilius sp. nov.

\section{Materials and methods}

Material of Petrolisthes virgilius sp. nov. collected in the Colombian regions of Santa Marta and the Gulf of Urabá was used for morphological examination and molecular analyses. Type material was deposited in the collection of the Museo de Historia Natural Marina de Colombia (INV CRU), INVEMAR (Institute of Marine and Coastal Research of Colombia, Santa Marta). Specimens were sexed and measured by using a stereoscope with a micrometer. Measurements are given in $\mathrm{mm}$ and correspond to carapace length, followed by carapace width.

DNA was extracted from the chelipeds or walking legs of seven specimens of the new species (3 from Santa Marta and 4 from the Gulf of Urabá) using the DNeasy Blood \& Tissue Kit (Qiagen), following the manufacturer's protocol for animal tissues. A $540 \mathrm{bp}$ fragment of the ribosomal $16 \mathrm{~S}$ rDNA was amplified using primers 16Sar (CGCCTGTTTATCAAAAACAT) and 16Sbr (CCGGTCTGAACTCAGATCACGT) (Palumbi 1996), and trimmed to 496 bp. Double-stranded amplifications were performed in $12 \mathrm{ml}$ volume reactions containing $2.5 \mu \mathrm{l}$ of Taq buffer $(5 \times), 1.7 \mu \mathrm{l}$ of dNTP mix $(8 \mathrm{mM}), 0.6 \mu \mathrm{l}$ of each primer $(10 \mu \mathrm{M}), 1.2 \mu \mathrm{l}$ of $\mathrm{MgCl}_{2}(25 \mathrm{mM}), 0.2 \mu \mathrm{l}$ of GoTaq Flexi DNA Taq Polymerase (Promega), $1 \mu$ l of DNA template, and $4.8 \mu \mathrm{l}$ of $\mathrm{ddH}_{2} 0$. Thermal cycling conditions consisted of an initial denaturation step at $96{ }^{\circ} \mathrm{C}$ for $3 \mathrm{~min}$, followed by 30 cycles of $95^{\circ} \mathrm{C}$ for $1 \mathrm{~min}, 50^{\circ} \mathrm{C}$ for $1 \mathrm{~min}$, and $72^{\circ} \mathrm{C}$ for 1 min. An extension step at $72^{\circ} \mathrm{C}$ for 5 min followed the last cycle. PCR products were cleaned using the ExoSap-IT kit (USB Corporation) following the manufacturer's protocol. Clean PCR products were cycle-sequenced in both directions using the BigDye Terminator v. 3.1 Cycle Sequencing Kit, and electrophoresed in an Applied Biosystems 3130 Genetic Analyzer. 

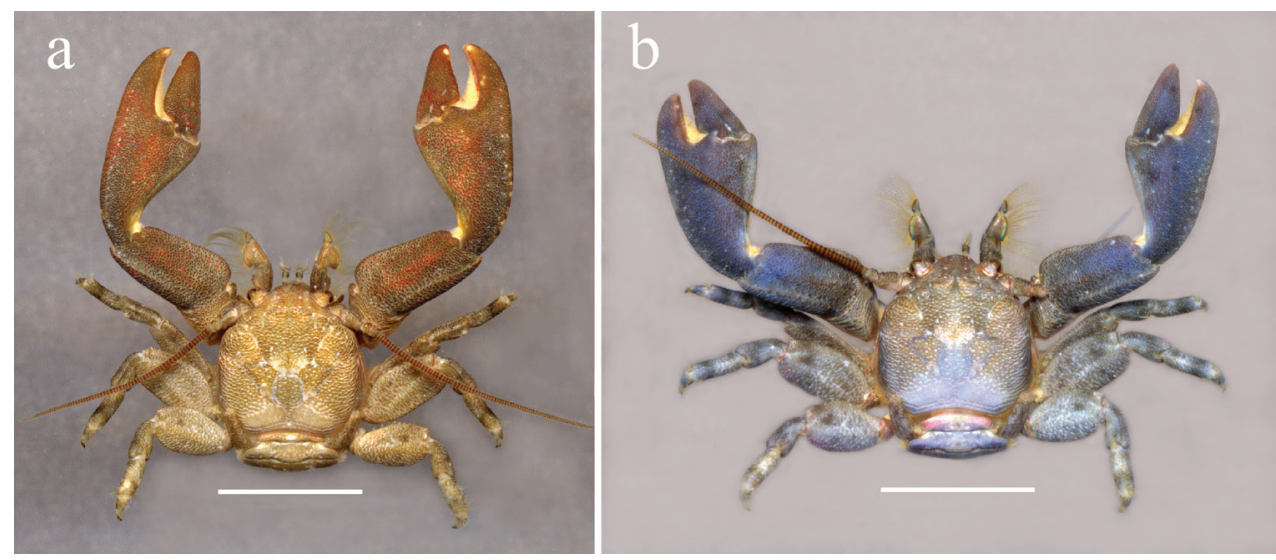

Figure I. Petrolisthes tonsorius, Venezuela, Isla Cubagua. a Brownish color morph b Blueish color morph. Scale bars: $3.7 \mathrm{~mm}(\mathbf{a}) ; 3.2 \mathrm{~mm}(\mathbf{b})$.

The $16 \mathrm{~S}$ rDNA sequences of $P$. virgilius sp. nov. were compared to two sequences of $P$. tonsorius from the Venezuelan Caribbean and the Colombian Pacific, published by Hiller et al. (2006) (GenBank accession numbers DQ444960 and DQ444959). The BioEdit Sequence Alignment Editor (Hall 1999) was used to trim primer regions from DNA sequences. MAFFT v. 7 (Katoh and Standley 2013) was used to align the sequences of $P$. virgilius sp. nov. and $P$. tonsorius. Genetic distances within and between these species were estimated using Kimura's two-parameter model (K2P; Kimura 1980) implemented in MEGA v. 7.0 (Kumar et al. 2016). GenBank accession numbers of the $16 \mathrm{~S}$ rDNA sequences of $P$. virgilius sp. nov. are MN275526-MN275532.

\section{Systematics}

\section{Family Porcellanidae Haworth, 1825}

\section{Petrolisthes virgilius sp. nov.}

http://zoobank.orgE0018D07-579A-4A53-84D1-2EF333D59098

Figs 2, 3a-e

Petrolisthes tonsorius Werding, 1978: 220 (not P. tonsorius Haig, 1960: 85-88)

Material. Holotype: male, INV CRU8404, Colombia, Chocó, Gulf of Urabá, Triganá, Napú, coll. J. Lazarus, 05 Dec. 2010; $4.6 \times 4.5$ mm.

Paratypes: 2 males, 2 females (1 ovigerous), INV CRU8405, same collection data as holotype. Size of males is $4.2 \times 3.7 \mathrm{~mm}$ and $3.3 \times 3.2 \mathrm{~mm}$; size of females is $5.3 \times 5.2 \mathrm{~mm}$ (ovigerous) and $4.3 \times 4.0 \mathrm{~mm}$ (Fig. 3). 


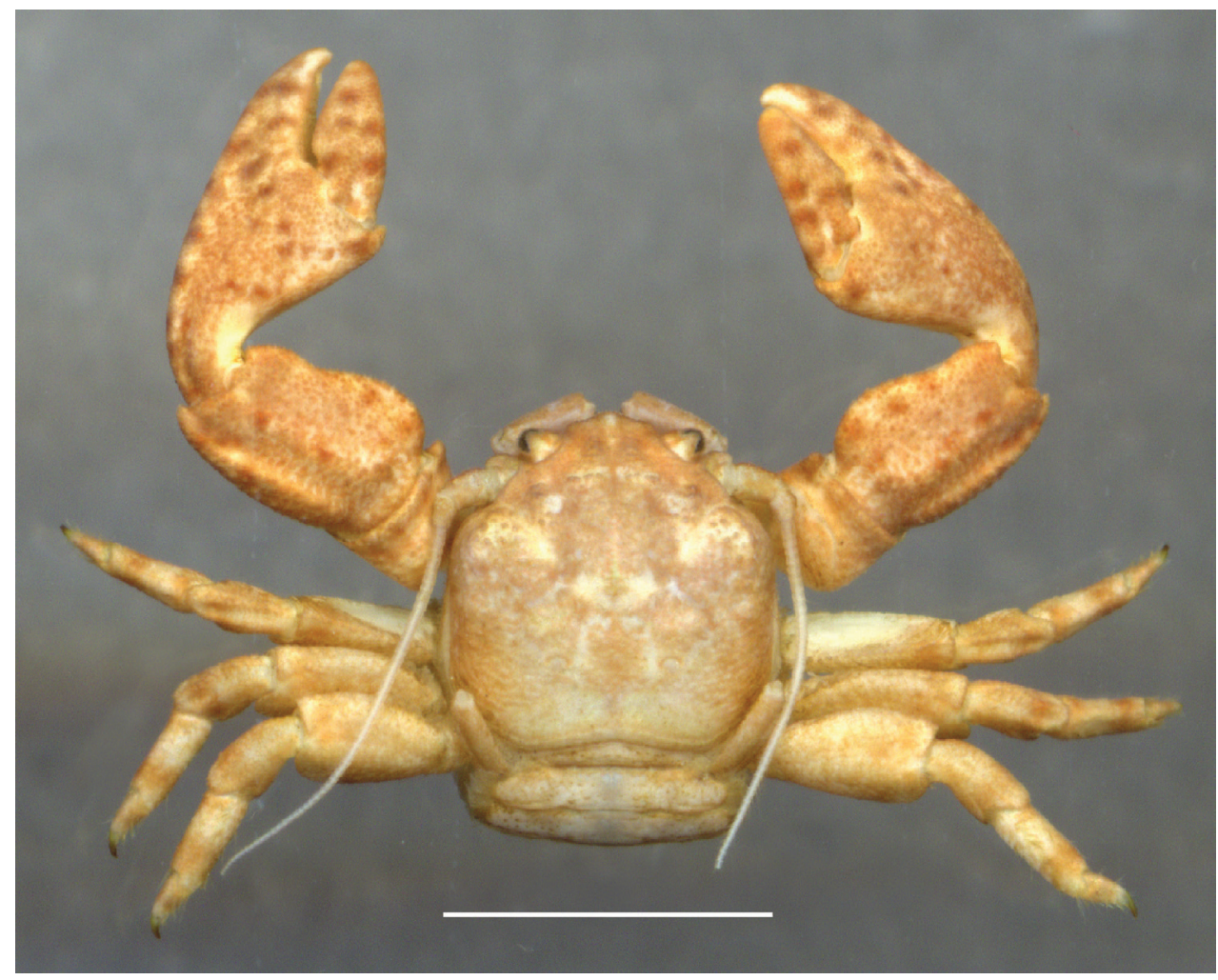

Figure 2. Petrolisthes virgilius sp. nov., Colombia, Santa Marta. Scale bar: $2.4 \mathrm{~mm}$.

Sizes of largest male and female reported by Werding (1978) are, respectively, $8.0 \times 8.1 \mathrm{~mm}$ and $6.5 \times 6.1 \mathrm{~mm}$.

Diagnosis. Carapace subquadrate, its margins subparallel posterior to epibranchial angle, nearly smooth, covered anteriorly with few flattened granules; no epibranchial spine; front narrow, triangular, with deep median groove; carpus $1 \frac{1}{2}$ times as long as wide, surface granulate, anterior margin with a broad, rounded lobe, separated through an indentation from a shallow distal lobe; manus with a longitudinal ridge; fingers blunt, outer margin convex, forming a rounded crest along entire length; merus of walking legs unarmed.

Description. Carapace about as long as broad, subquadrate, lateral margins subparallel posterior to epibranchial angles; nearly smooth, covered anteriorly with few flattened granules and posteriorly with light plications; grooves marking the various regions distinct. No epibranchial spine. Front narrow, triangular, strongly produced, with a deep median groove extending between protogastric lobes; no supraocular spine; inner orbital angle not produced. Orbits rather shallow; outer orbital angle produced into a small tooth. Eyes moderately large. Carapace naked. Basal segments of antennae thick, granulate, first movable segments with a marked crest produced to distal edge, second massive and cylindrical, flagellum about $1 \frac{1 / 2}{2}$ as long as carapace. 


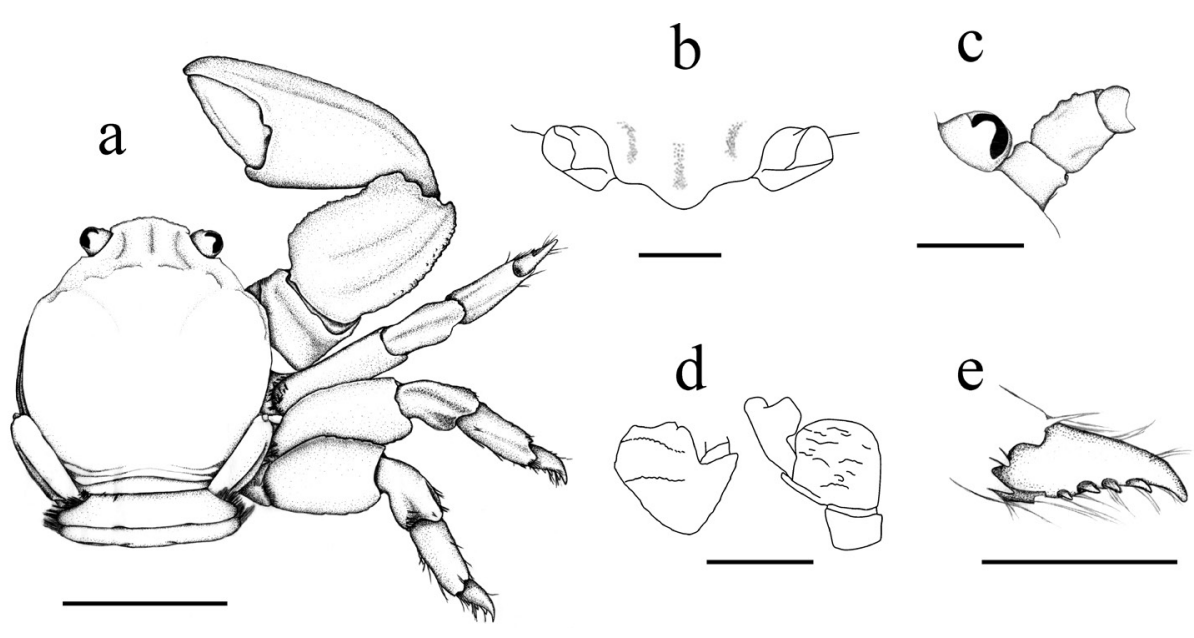

Figure 3. Petrolisthes virgilius sp. nov., female (ovigerous) paratype, INV-CRU 8405, Colombia, Chocó, Gulf of Urabá, Triganá, Napú. a Dorsal view b rostrum, frontal view $\mathbf{c}$ orbit with basal segments of antenna d basal segment of antennular peduncle e dactylus of last right walking leg. Scale bars: $5.0 \mathrm{~mm}(\mathbf{a}) ; 1.0 \mathrm{~mm}(\mathbf{b}-\mathbf{e})$.

Chelipeds broad, naked, covered with small flattened granules on dorsal surface, smooth ventrally. Merus with a small granular lobe on anterior margin, inner distal edge not produced. Carpus ca. 11/2 times as long as broad, surface granulate, anterior margin produced into a broad, rounded lobe extending $2 / 3$ of its length, and separated through an indentation from a shallow distal lobe; dorsal surface with a broad, longitudinal ridge. Posterior border convex, forming a granulate crest, ending distally in a rounded tooth. Chelae subequal, moderately large. Manus with a longitudinal ridge. Fingers blunt, pollex frequently longer than dactylus, outer margin convex, forming a rounded crest along entire length; dactylus longitudinally notched. Gape without pubescence.

Walking legs compact, with scattered simple setae. Merus unarmed, broad, flattened; carpus and propodus naked, crested above, dactylus with four movable spinules on inner border.

Telson with seven plates.

Coloration. The overall coloration of P. virgilius sp. nov. is pale brown to beige, the brown coloration prevailing on chelipeds and frontal half of carapace (Fig. 2). Carpus and manus of chelipeds frequently show scattered, dark-brown spots.

Ecology. Petrolisthes virgilius sp. nov. was found exclusively in intertidal formations of vermetid snails exposed to strong waves. The new species shares this habitat with Neopisosoma angustifrons (Benedict, 1901), N. neglectum Werding, 1986, and Clastotoechus nodosus (Streets, 1872). The latter species can also be found in other intertidal fouling incrustations in heavily wave-exposed rocky shores (Werding 1986).

Distribution. Colombia, Santa Marta and Gulf of Urabá regions.

Etymology. The new species is named after Dr. Virgilio Galvis Ramírez MD for his support and interest in our research on marine crabs, and for his contributions to medical sciences in Colombia. 
Molecular analysis. The 496 bp alignment consisting of seven $16 \mathrm{~S}$ rDNA sequences of Petrolisthes virgilius and two of $P$. tonsorius revealed two haplotypes within the new species, which differ only by one nucleotide. One haplotype was more frequent than the other and was shared by two individuals from Santa Marta and three from the Gulf of Urabá. The other haplotype was shared by two individuals from Santa Marta. The average of genetic distance within the new species was $0.2 \%$. Distances between P. virgilius and P. tonsorius ranged between $9.6 \%$ and $10.2 \%$. The average distance between populations of $P$. tonsorius from the Pacific and Caribbean was $4.8 \%$.

Remarks. Petrolisthes virgilius can be distinguished morphologically from $P$. tonsorius and similar species by the marked granulation of carapace and extremities, the marked indentation of the anterior margin of the cheliped's carpus, and the accentuated crests of the chelipeds.

\section{Discussion}

The new species belongs to one of the morphological lines in the diverse and worldwide distributed genus Petrolisthes. This morphological line is strictly American and includes species lacking spines and dentations in carapace and extremities. In the West Atlantic this group is represented by two trans-isthmian species, $P$. tridentatus Stimpson, 1859, and P. tonsorius Haig, 1960, and by P. quadratus Benedict, 1901, P. gertrudae Werding, 1996, P. hispaniolensis Werding \& Hiller, 2005, and now P. virgilius. Besides the two trans-isthmian species, the East Pacific members of this group are numerous, and are morphologically represented by the tropical $P$. galapagensis Haig, 1960, and a number of subtropical, warm-temperate and temperate species (see Haig 1960). Despite the close resemblance between $P$. virgilius and P. tonsorius, which led Werding (1978) to cautiously consider them conspecific, the large $16 S$ genetic distance and distinguishing color and habitat confirms that they are different species. The genetic distance is double to that between individuals of $P$. tonsorius from each side of the Isthmus of Panama and surpasses by far the distance of $1.5 \%$ found by Hiller et al. (2006) for the trans-isthmian P. armatus Gibbes, 1850. The high molecular divergence between $P$. virgilius and $P$. tonsorius seems to be accompanied by species-specific coloration. However, intraspecific variation in color in $P$. tonsorius from each side of the Isthmus of Panama overlaps and therefore, in this case, color does not distinguish populations from each ocean. The crabs from both the East Pacific and West Atlantic display carapace and extremities that vary from brown to blueish. Haig (1960) described $P$. tonsorius from preserved specimens collected in the Galápagos Islands and surmised that they were blueish-colored in life. She wrote (p. 87): "After more than twenty years in alcohol, a few specimens show a dark blue-violet on the metabranchial regions of the carapace, ringed by a darker line of the same color; this shade of blue is also present on the eyestalks, movable segments of the antennae, walking legs, telson of the abdomen, and palps of the maxillipeds". Color and color pattern have been taxonomically reliable characters for distinguishing cryptic species of porcellanids (Hiller 
et al. 2006; Hiller and Werding 2007) and other anomurans like hermit crabs (Malay et al. 2012; Negri et al. 2014) and squat lobsters (Macpherson and Machordom 2001; Cabezas et al. 2011). However, in some species complexes in Anomura color may not vary interspecifically (Werding and Hiller 2017) or it can vary intraspecifically (Rodríguez-Flores et al. 2018).

Petrolisthes virgilius is ecologically unique compared to its morphological allies, typically occurring under intertidal boulders moderately to highly exposed to water movement. The only other species in association with living organisms is $P$. gertrudae, occasionally found on Zoanthus sociatus (Ellis, 1768) (see Werding 1996). The vermetid conglomerates where P. virgilius was found in Santa Marta and the Gulf of Urabá are cemented to a beachrock platform exposed to strong waves, which provide the vermetids and associated fauna with oxygen and nutrients. This singular vermetid habitat provides shelter to other porcellanid species of genera Neopisosoma Haig, 1960, and Clastotoechus Haig, 1960. The new species seems to have evolved in tight association to intertidal vermetid formations exposed to extremely strong water movement.

Including the new species, the genus Petrolisthes now comprises 111 species and the family Porcellanidae 305 species.

\section{Acknowledgements}

We thank the following colleagues for their contributions to this manuscript: H.A. Lessios for commenting on the manuscript, and L. Geyer, L. Rivera, and A. Calderón (STRI) for support in the laboratory; J. Lazarus (Universidad del Valle, Cali) for collecting part of the crab material; E. Macpherson (Centro de Estudios Avanzados de Blanes - CEAB), E. Campos (Universidad Autónoma de Baja California) and I. Wehrtmann (Universidad de Costa Rica) for improving an earlier version of this manuscript; C. Arteaga, E. Montoya, and M. Martelo (INVEMAR) for logistic help. This study was supported by a Smithsonian Postdoctoral Fellowship to A.H.

\section{References}

Benedict JE (1901) The anomuran collections made by the Fish Hawk Expedition to Porto Rico. Bulletin of the United States Fish Commission 20: 131-148.

Cabezas P, Macpherson E, Machordom A (2011) Allogalathea (Decapoda: Galatheidae): a monospecific genus of squat lobster? Zoological Journal of the Linnean Society 162: 245-270. https://doi.org/10.1111/j.1096-3642.2010.00681.x

Ellis J (1768) An account of the Actinia sociata, or clustered animal-flower, lately found on the sea-coasts of the new-ceded islands. Philosophical Transactions of the Royal Society of London 57: 428-437. https://doi.org/10.1098/rstl.1767.0043

Ferreira LAA, Tavares M (2017) A new species of Pachycheles (Crustacea: Anomura: Porcellanidae), with taxonomic remarks on two other porcelain crabs from the remote oceanic 
archipelago of Trindade and Martin Vaz, South Atlantic Ocean. Zootaxa 4299: 546-650. https://doi.org/10.11646/zootaxa.4299.4.5

Ferreira LAA, Tavares M (2019) A review of the records of Pachycheles rugimanus A. MilneEdwards, 1880 (Crustacea: Decapoda: Anomura: Porcellanidae) from Brazil, with the description of a new species. Zootaxa 4568: 185-193. https://doi.org/10.11646/ zootaxa.4568.1.12

Gibbes LR (1850) On the carcinological collections of the United States, and an enumeration of species contained in them with notes on the most remarkable, and descriptions of new species. Proceedings of the American Association for the Advancement of Science 3: 167-201.

Haig J (1960) The Porcellanidae (Crustacea Anomura) of the eastern Pacific. Allan Hancock Pacific Expeditions 24: 1-440.

Hall TA (1999) BioEdit: a user-friendly biological sequence alignment editor and analysis program for Windows 95/98/NT. Nucleic Acids Symposium Series 41: 95-98.

Haworth AH (1825) A new binary arrangement of the macrurous Crustacea. Philosophical Magazine and Journal 65: 183-184. https://doi.org/10.1080/14786442508628417

Hiller A, Werding B (2007) Description of a new species of the genus Petrolisthes from the eastern Pacific based on morphological and molecular characters (Crustacea: Anomura: Porcellanidae). Organisms, Diversity and Evolution 7: 181-194. https://doi.org/10.1016/j. ode.2006.06.002

Hiller A, Kraus H, Almon M, Werding B (2006) The Petrolisthes galathinus complex: Species boundaries based on color pattern, morphology and molecules, and evolutionary interrelationships between this complex and other Porcellanidae (Crustacea: Decapoda: Anomura). Molecular Phylogenetics \& Evolution 40: 547-569. https://doi.org/10.1016/j. ympev.2006.03.030

Katoh K, Standley DM (2013) MAFFT multiple sequence alignment software version 7: improvements in performance and usability. Molecular Biology \& Evolution 30: 772-780. https://doi.org/10.1093/molbev/mst010

Kimura M (1980) A simple method for estimating evolutionary rates of base substitutions through comparative studies of nucleotide sequences. Journal of Molecular Evolution 16: 111-120. https://doi.org/10.1007/BF01731581

Kumar S, Stecher G, Tamura K (2016) MEGA 7: Molecular Evolutionary Genetics Analysis version 7.0 for bigger datasets. Molecular Biology and Evolution 33: 1870-1874. https:// doi.org/10.1093/molbev/msw054

Macpherson E, Machordom A (2001) Phylogenetic relationships of species of Raymunida (Decapoda: Galatheidae) based on morphology and mitochondrial cytochrome oxidase sequences, with the recognition of four new species. Journal of Crustacean Biology 21: 696-714. https://doi.org/10.1163/20021975-99990168

Malay MC, Komai T, Chan TY (2012) A new cryptic species in the "Calcinus anani Poupin \& McLaughlin, 1998” species complex (Decapoda: Anomura: Diogenidae): evidence from colouration and molecular genetics. Zootaxa 3367: 165-175. https://doi.org/10.11646/ zootaxa.3367.1.16 
Negri M, Lemaitre R, Mantelatto FL (2014) Molecular and morphological resurrection of Clibanarius symmetricus (Randall, 1840), a cryptic species hiding under the name for the "thinstripe" hermit crab C. vittatus (Bosc, 1802) (Decapoda: Anomura: Diogenidae). Journal of Crustacean Biology 34: 848-861. https://doi.org/10.1163/1937240X-00002277

Palumbi S (1996) Nucleic Acids II: The Polymerase Chain Reaction. In: Hillis DM, Moritz C, Mable BK (Eds) Molecular Systematics, 205-247. https://doi.org/10.2307/1447682

Rodríguez-Flores PC, Macpherson E, Machordom A (2018) High morphological similarity coupled with high genetic differentiation in new sympatric species of coral-reef squat lobsters (Crustacea: Decapoda: Galatheidae). Zoological Journal of the Linnean Society 185: 984-1017. https://doi.org/10.1093/zoolinnean/zly074

Stimpson W (1859) Notes on North American Crustacea, No.1. Annals of the Lyceum of Natural History New York, 7: 49-93. https://doi.org/10.1111/j.1749-6632.1862.tb00142.x

Streets TH (1872) Notice of some Crustacea from the island of St. Martin, W. I., collected by Dr. Van Rijgersma. Proceedings of the Academy of Natural Sciences of Philadelphia 24: 131-134.

Werding B (1978) Los porcelánidos (Crustacea: Anomura: Porcellanidae) de la región de Acandí (Golfo de Urabá) con algunos encuentros nuevos de la región de Santa Marta (Colombia). Anales del Instituto de Investigaciones Marinas de Punta de Betín 10: 213-221. https://doi.org/10.25268/bimc.invemar.1978.10.0.514

Werding B (1986) Die Gattung Neopisosoma Haig, 1960 im tropischen Westatlantik mit Beschreibung von Neopisosoma neglectum spec. nov. und Neopisosoma orientale spec. nov. (Crustacea: Anomura: Porcellanidae). Zoologische Mededelingen 60: 159-179. http:// www.repository.naturalis.nl/document/150177

Werding B (1996) Description of a new porcellanid Petrolisthes gertrudae from the southeastern Caribbean Sea (Crustacea: Decapoda: Porcellanidae). Proceedings of the Biological Society of Washington 109: 306-310.

Werding B, Hiller A (2005) A new porcellanid species from the Caribbean Sea, with a discussion on the American "Petrolisthes lewisi-group" (Decapoda, Anomura, Porcellanidae). Crustaceana 78: 1185-1190. https://doi.org/10.1163/156854005775903582

Werding B, Hiller A (2017) Description of a new species of Pachycheles (Decapoda, Anomura, Porcellanidae) from the southern Caribbean Sea. Crustaceana (Michael Türkay Memorial Issue) 90: 1279-1288. https://doi.org/10.1163/15685403-00003684 